\title{
Foraging behavior of Melipona rufiventris Lepeletier (Apinae; Meliponini) in Ubatuba, SP, Brazil
}

\author{
Fidalgo, AO. ${ }^{\text {a* }}$ and Kleinert, $A M P{ }^{\mathrm{b}}$

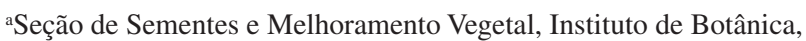 \\ CP 4005, CEP 01061-970, São Paulo, SP, Brazil \\ bDepartamento de Ecologia, Instituto de Biociências, Universidade de São Paulo, São Paulo \\ *e-mail: aofidalgo@yahoo.com.br \\ Received February 11, 2005 - Accepted February 20, 2006 - Distributed February 28, 2007
}

(With 5 figures)

\begin{abstract}
This study describes how the foraging activity of Melipona rufiventris is influenced by the environment and/or by the state of a colony. Two colonies were studied in Ubatuba, SP (44 ${ }^{\circ} 48^{\prime} \mathrm{W}$ and $23^{\circ} 22^{\prime}$ S) from July/2000 to June/2001. These colonies were classified as strong (Colony 1 ) and intermediate (Colony 2 ) according to their general conditions: population and brood comb size and number of food pots. The bees were active from dawn to dusk. The number of pollen loads presented a positive correlation with relative humidity $\left(r_{s}=0.401 ; p<0.01\right)$ and was highest between 70 and $90 \%$. However, it was negatively correlated with temperature $\left(r_{s}=-0.228 ; p<0.01\right)$ showing a peak between 18 and $23{ }^{\circ} \mathrm{C}$. The number of nectar loads presented a positive correlation with temperature $\left(r_{s}=0.244 ; p<0.01\right)$ and light intensity $\left(r_{s}=0.414 ; \mathrm{p}<0.01\right)$; it was greater between 50 and $90 \%$ of relative humidity and 20 and $30{ }^{\circ} \mathrm{C}$ of temperature. They collected more nectar than pollen throughout the day, and were more active between 6 and 9 hours. Workers from Colony 1 (strong) collected nectar in greater amounts and earlier than those from Colony 2 (intermediate). The number of pollen, nectar and resin loads varied considerably between the study days. Peaks of pollen collection occurred earlier in months with longer days and in a hotter and more humid climate. The foraging behavior of M. rufiventris is probably affected by the state of the colony and by environmental conditions, notably temperature, relative humidity, light intensity and length of the day.
\end{abstract}

Keywords: Melipona rufiventris, Apinae, Meliponini, foraging behavior, nectar, pollen.

\section{Comportamento de forrageamento de Melipona rufiventris Lepeletier (Apinae; Meliponini) em Ubatuba, SP, Brasil}

\begin{abstract}
Resumo
Este estudo descreve como a atividade de forrageamento de Melipona rufiventris é influenciada pelo ambiente e/ou pelo estado da colônia. Duas colônias foram estudadas em Ubatuba, SP (44 $48^{\prime} \mathrm{W}$ and $23^{\circ} 22^{\prime}$ S), de julho de 2000 a junho de 2001. Estas colônias foram classificadas como forte (Colônia 1) e intermediária (Colônia 2), de acordo com as condições gerais das mesmas: tamanho da população e dos favos de cria e número de potes de alimento. As abelhas foram ativas do amanhecer ao anoitecer. O número de cargas de pólen apresentou correlação positiva com a umidade relativa $\left(\mathrm{r}_{\mathrm{s}}=0,401 ; \mathrm{p}<0,01\right)$ e foi maior entre 70 e $90 \%$. Entretanto, foi negativamente relacionado com a temperatura $\left(r_{s}=-0,228 ; p<0,01\right)$, com pico entre 18 e $23{ }^{\circ} \mathrm{C}$. O número de cargas de néctar apresentou correlação positiva com a temperatura $\left(r_{s}=0,224 ; p<0,01\right)$ e com a intensidade luminosa $\left(r_{s}=0,414 ; p<0,01\right)$; sendo maior entre 50 e $90 \%$ de umidade relativa e entre 20 e $30^{\circ} \mathrm{C}$ de temperatura. Elas coletaram mais néctar do que pólen ao longo do dia, sendo mais ativas entre 6 e 9 hours. A Colônia 1 (forte) coletou néctar em maiores quantidades e mais cedo que a colônia 2 (intermediária). O número de cargas de pólen, néctar e resina coletadas variou consideravelmente entre os dias de estudo. Os picos de coleta de pólen ocorreram mais cedo nos meses com dias mais longos e com clima mais quente e úmido. O comportamento de forrageio de $M$. rufiventris é provavelmente afetado pelo estado da colônia e por condições ambientais como temperatura, umidade relativa, intensidade luminosa e comprimento do dia.
\end{abstract}

Palavras-chave: Melipona rufiventris, Apinae, Meliponini, comportamento de forrageio, néctar, pólen. 


\section{Introduction}

Foraging activity of bees is influenced by climatic conditions, food availability, competition, colony state, and individuals' morphology and physiology (Sommeijer et al., 1983; Ramalho et al., 1985; Ramalho et al., 1989; Roubik, 1989).

The main climatic conditions that affect the flight and foraging behavior of bees are temperature, light intensity and relative humidity (Kleinert-Giovannini, 1982; Corbet et al., 1993). Foraging can be hampered by rain and wind speed; continuous rainfall can cause a reduction in flight activity which, on the other hand, is not particularly disturbed by mild rain (Sommeijer et al., 1983). Other factors, especially attractive flowers and swarming, are important influences on the foraging pattern (Iwama, 1977).

In the tropical plains, most of the eusocial bees show activity peaks in the morning, with a peak of pollen collection occurring before the nectar peak (Roubik, 1989). Some authors demonstrated the same pattern for the genus Melipona (Sommeijer et al., 1983; Biesmeijer, 1997; Bruijn and Sommeijer, 1997; Cortopassi-Laurino, 2004). Pollen peaks in the morning are related to a greater availability of the resource at this time and, consequently, to competition with other bees for this limited resource (Roubik, 1989). Sugar concentrations in the nectar increase during the day and the sources of this resource are only visited when the concentration has reached optimum levels (Roubik and Buchmann, 1984).

The number of individuals comprising a given colony defines its characterization as weak, intermediate or strong, which, in turn, is the result of internal and external factors (Hilário et al., 2000). According to Sommeijer et al. (1983), the breath of the pollen spectrum of different species of bees has a closer relationship with a colony's population size than with the body size of bees: colonies consisting of a larger number of bees had a wider pollen spectrum. However, the external activity depends on the body size of the insects. Larger species usually fly at lower temperatures and light intensities than their smaller counterparts (Käpylä, 1974) and strong colonies produce larger bees than the intermediate and weak ones (Lacerda et al., 1991). In Melipona bicolor bicolor, foragers of stronger colonies begin flight activity earlier and at lower temperatures than those of intermediate and weak colonies (Hilário et al., 2000).

This study describes how the flight and foraging activity of Melipona rufiventris are correlated with abiotic factors and with the colony state and investigates the occurrence of cyclical patterns in the pollen and nectar collection by this species.

\section{Material and Methods}

This work was done in a forest area on the coastal plain of Praia de Fazenda, located on the northern side of the district of Ubatuba, São Paulo state, at approximately $44^{\circ} 48^{\prime} \mathrm{W}$ and $23^{\circ} 22^{\prime} \mathrm{S}$. This plain is formed by a mosaic of vegetation types that include beaches, dunes, mangrove swamps, paludal forests and forest formations on coastal strips. The climate of the area, according to the classification by Köppen (1948), and reviewed by Herrera et al. (1997), is of the Af type, or tropical rain, with rainfall throughout the year, a mean annual precipitation of 2,650 mm, a mean temperature of $21.9^{\circ} \mathrm{C}$ and relative humidity always greater than $85 \%$.

Two colonies of Melipona rufiventris were installed in June, 2000, 5 meters apart, within the coastal plain forest, close to a mangrove swamp. One of these colonies was removed from a fig tree in the area of the hillside forest inside the study site (Colony 1 ); the other was transferred from the region of São Simão/São Paulo state (Colony 2). They were classified as strong and intermediate, respectively, according to their general conditions, population and brood comb size as well as the number of food pots. According to Camilo-Atique (1974) strong colonies of Melipona rufiventris have, approximately, 1,000 cells in their combs and 20 food pots; weak colonies have 600 comb cells and less than 10 food pots.

Colonies were evaluated once a month at intervals of approximately 28 to 30 days, from July 2000 to June 2001. Observations began at sunrise and extended until evening, for a period of 13 to 14 hours, depending on the length of the day, making a total of 161 hours of observations.

Once an hour, the entrance of each colony was blocked for 5 minutes and the returning bees were collected with an aspirator. Nectar was extracted from them through their mouth parts, with calibrated capillary tubes, while their abdomens were pressed dorsal-ventrally (Roubik and Buchmann, 1984). Pollen and resin foraging bees were easily recognized by the presence of these materials in their corbiculae. Bees with pollen, nectar, resin or without any load were counted. Temperature, relative humidity and light intensity were recorded. Temperature and relative humidity were measured with the aid of a digital thermo hygrometer, installed close to one of the colonies. Light intensity was measured using a hand photometer, positioned at 90 degrees relative to the sun. Data regarding the monthly mean temperature and total accumulated rainfall in the period of 19901999 were obtained from INMET (National Institute of Meteorology). A cluster analysis was performed with these data using the MVSP software to investigate the occurrence of periods that could be considered as seasons. Temperature and rainfall values were transformed in proportions by dividing the highest value observed for each of these measures.

Results were analyzed using circular statistics (Batschelet, 1981). Circular statistics works with the analysis of points around a circle; the acrophase or mean angle is the phase in which there is a greater probability of an activity to be observed. Statistical difference was obtained by Rayleigh's test of (Zar, 1999). To compare the acrophases of resource collection between colonies and between the collected materials, we used the Watson- 
William's test (Zar, 1999), in which the null hypothesis affirms that the acrophases are the same. Correlation between flight activity and abiotic factors was carried out using the Spearman non-parametric test (Zar, 1999).

\section{Results}

Bees collected proportionally more nectar than pollen throughout the day, while resin was, in general, collected in larger amounts only at the beginning and at the end of the day (Figure 1). Bees without loads were observed from 5 to 17 hours. There are no data from 18 hours for Colony 2 because observations related to this colony were done close to the sunset when it was already too dark for the bees' flight activity inside the forest. Temperature, relative humidity and light intensity varied throughout the day in the study area. Temperature and light intensity tended to increase concomitantly $\left(r_{s}=0.310 ; p<0.01\right)$ and relative humidity decreased as the temperature increased $\left(r_{s}=-0.344 ; p<0.01\right)$. The mean number of pollen loads was higher between 16 and $24{ }^{\circ} \mathrm{C}$ and between a relative humidity of 70 and $90 \%$. Nectar loads were collected within a wide range of temperatures and relative humidity, $20-30{ }^{\circ} \mathrm{C}$ and $50-90 \%$, respectively. The number of pollen loads decreased when the temperature increased $\left(r_{s}=-0.228 ; \mathrm{p}<0.01\right)$ and was positively correlated with relative humidity $\left(r_{s}=0.401\right.$; $\mathrm{p}<0.01)$. The number of nectar loads presented a positive correlation with both temperature and relative humidity for Colony $1\left(r_{s}=0.244 ; p<0.01\right.$ and $r_{s}=0.155$; $\mathrm{p}<0.05$, respectively); for Colony 2 there was no such correlation. However, in both colonies there was a correlation between the number of nectar loads and light intensity $\left(\mathrm{r}_{\mathrm{s} 1}=0.377 ; \mathrm{p}<0.01\right.$ and $\mathrm{r}_{\mathrm{s} 2}=0.456$; $\left.\mathrm{p}<0.01\right)$. The number of pollen loads tended to increase with the number of nectar loads $\left(r_{s}=0.412 ; p<0.01\right)$. The greater the amount of nectar and pollen collected, the more bees entered the hive without any load $\left(\mathrm{r}_{\mathrm{s}}=0.373\right.$; $\mathrm{p}<0.01$; $r_{s}=0.239 ; \mathrm{p}<0.01$, for Colonies 1 and 2 respectively). Only for Colony 2 the number of bees without any load increased with the increase of light intensity $\left(r_{s}=0.292\right.$; $\mathrm{p}<0.01$ ). The number of resin loads tended to increase with the number of bees with nectar or pollen loads for Colony $1\left(r_{s}=0.256 ; p<0.01 ; r_{s}=0.366 ; p<0.01\right.$, respectively) and only with pollen loads for Colony 2 $\left(r_{s}=0.226 ; p<0.01\right)$ (Figure 1).

When analyzed together, both colonies presented a peak of pollen collection at about 6 hours, and that of nectar at about 9 hours (Figure 2). In Colony 1, at 6 hours, pollen collection was at least two times of that of the remaining period. Colony 2 foraged for pollen mostly one hour earlier.

Between December and March pollen collection occurred earlier on the longer and hotter days. Consequently, a circular statistical analysis was carried out considering 6 months with shorter days (April to September, 11-10 hours) and the remaining 6 months with longer days (October to March, 12-13 hours). The results demonstrated that the peak of pollen collection oc-

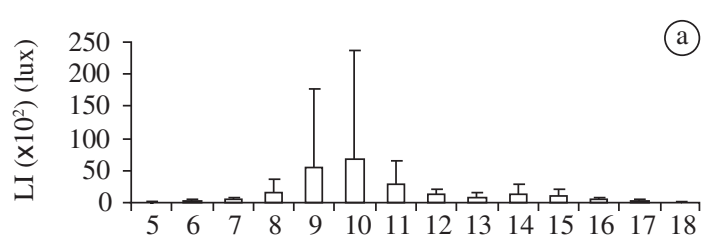

(b)
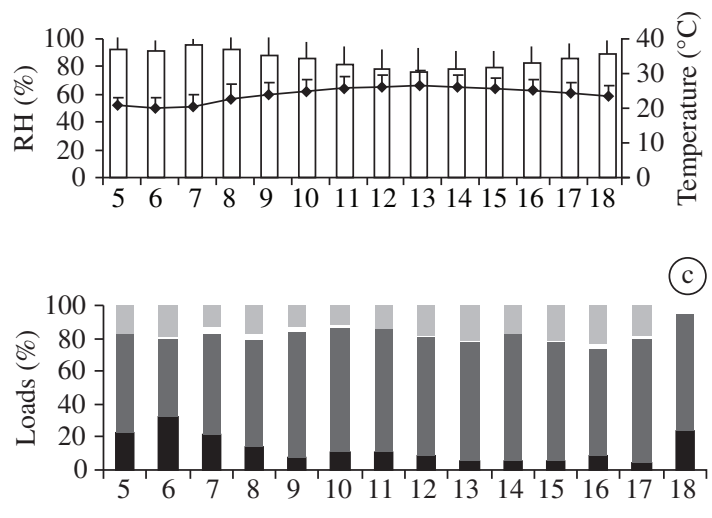

(d)

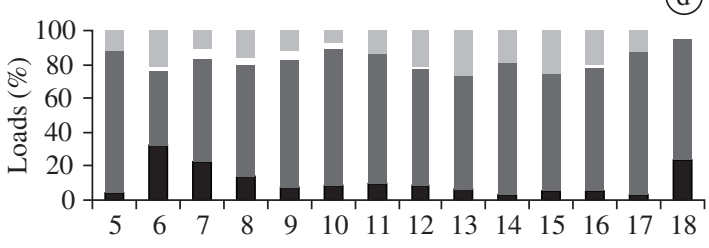

(e)

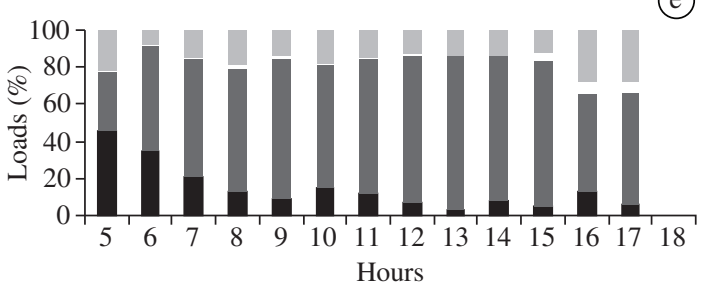

Figure 1. Daily values for light intensity a), relative humidity and temperature b), and frequency (\%) of foragers of Melipona rufiventris entering the colony with or without material: Colony 1 and $2 \mathrm{c}$ ), Colony $1 \mathrm{~d}$ ), Colony $2 \mathrm{e}$ ).

curred about two hours earlier in the months with longer days, although there was little difference for the nectar peak (Table 1). The comparison between the acrophases revealed a significant difference in the peaks of pollen collection between months with long and short days, both for Colony $1(\mathrm{~F}=59.150 ; \mathrm{p}<0.05)$ and Colony 2 $(\mathrm{F}=48.566 ; \mathrm{p}<0.05)$. 
Results from the cluster analysis of the climatic data showed the occurrence of three distinct periods and one month of transition in Ubatuba (Figure 3). The most humid and hot period occurred from January to March, followed by one month of transition (April), then a dry and
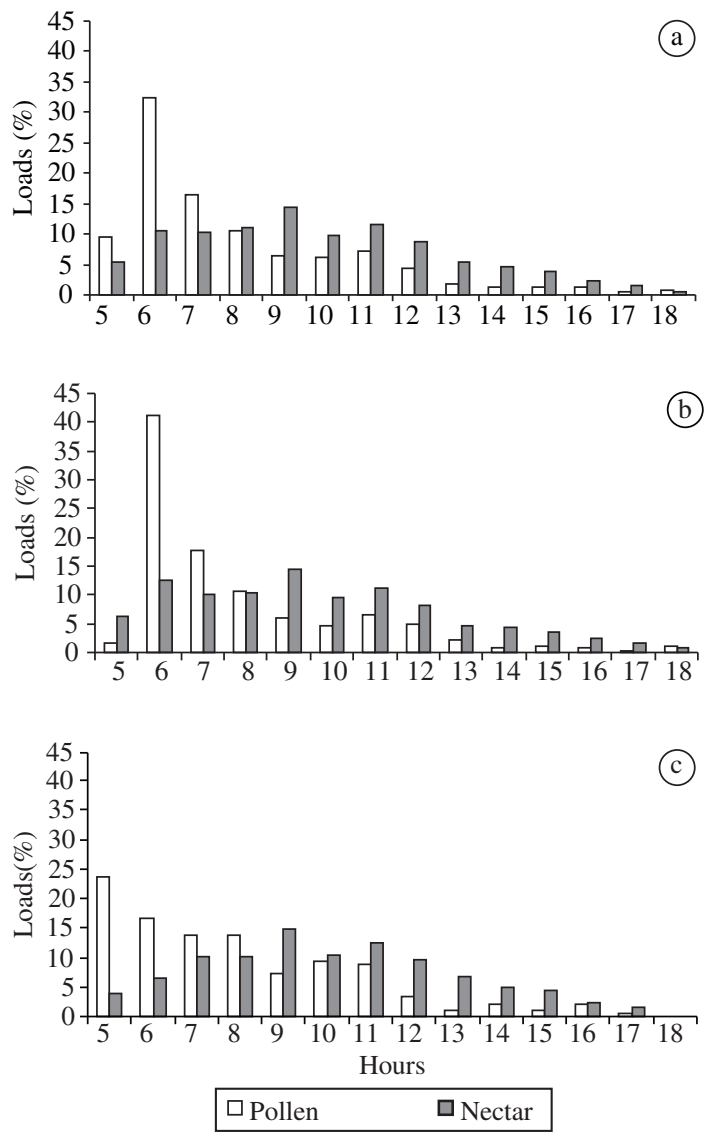

Figure 2. Daily pattern of nectar and pollen collection by Melipona rufiventris in Ubatuba, SP. a) Colony 1 and 2; b) Colony 1; and c) Colony 2 . cold period from May to August and finally a humid and hot period from September to December.

To test the influence of these climatic changes on the foraging behavior of Melipona rufiventris, foraging data were grouped according to the above mentioned periods and analyzed once more through circular statistics. Peaks of pollen and nectar collection were closer in the cold and dry period (May to August) and tended to move apart as the climate became increasingly hot and humid (September to March) (Table 2). There was no statistically significant difference between peaks of pollen and nectar collection in the dry period, either for Colony 1 $(\mathrm{F}=0.00 ; \mathrm{p}<0.05)$ or Colony $2(\mathrm{~F}=1.21 ; \mathrm{p}<0.05)$. In April, rainfall decreased by half, but the temperature remained high $\left(\sim 23{ }^{\circ} \mathrm{C}\right)$; nevertheless peaks of pollen and nectar collection began to converge.

There was a significant difference of pollen and nectar acrophases between the dry period and the other two periods and the month of transition in both colonies (Table 3). On the other hand, peaks of pollen collection



Figure 3. Dendrogram showing the result of the cluster analysis, grouped for each month, according to the proportion of the mean monthly temperature and accumulated rainfall over ten years from 1990 to 1999 (temperature and rainfall values were divided by the highest value observed in each one of these).

Table 1. Comparison of the acrophases for nectar and pollen collection by foragers of Melipona rufiventris in the months with short days (Apr-Sept) and long days (Oct-Mar). Significance of the acrophases according to Rayleigh's test.

\begin{tabular}{|c|c|c|c|c|c|c|}
\hline \multirow[t]{2}{*}{ Colony } & \multicolumn{3}{|c|}{ April-September } & \multicolumn{3}{|c|}{ October-March } \\
\hline & $1 *$ & $2 * *$ & Total & $1 *$ & $2 * *$ & Total \\
\hline $\mathrm{N}^{\circ}$ of nectar loads & 632 & 375 & 1007 & 883 & 380 & 1263 \\
\hline Acrophase (h:min) ${ }^{1}$ & $9: 37$ & $9: 48$ & $9: 41$ & $9: 14$ & 10:02 & $9: 29$ \\
\hline $\mathrm{r}$ & 0.792 & 0.789 & 0.791 & 0.665 & 0.715 & 0.677 \\
\hline Conclusion $^{2}$ & $\mathrm{~S}$ & $\mathrm{~S}$ & $\mathrm{~S}$ & $\mathrm{~S}$ & $\mathrm{~S}$ & $\mathrm{~S}$ \\
\hline $\mathrm{N}^{\mathrm{o}}$ of pollen loads & 83 & 73 & 156 & 244 & 118 & 352 \\
\hline Acrophase (h:min) ${ }^{1}$ & $9: 27$ & $9: 41$ & $9: 33$ & $7: 37$ & $6: 52$ & $6: 53$ \\
\hline $\mathrm{r}$ & 0.803 & 0.766 & 0.785 & 0.845 & 0.832 & 0.851 \\
\hline Conclusion $^{2}$ & $\mathrm{~S}$ & $\mathrm{~S}$ & $\mathrm{~S}$ & $\mathrm{~S}$ & $\mathrm{~S}$ & $\mathrm{~S}$ \\
\hline
\end{tabular}

${ }^{1}$ Local time: reference $=$ midnight local $=00^{\circ} ;{ }^{2} \mathrm{~S}=$ significant $(\mathrm{p}<0.05) ; *$ strong; and $* *$ intermediate. 
in Colony 1 were statistically similar from September to April (Table 3). Peaks of pollen $(F=9.16 ; p<0.05)$ and nectar $(\mathrm{F}=8.47 ; \mathrm{p}<0.05)$ were also significantly different between Colonies 1 and 2 in the hottest and most humid period (January to March) and in the transition month (April) for pollen peak $(\mathrm{F}=4.37$; $\mathrm{p}<0.05)$.

The greatest number of pollen loads was collected from January to March, while the peak of nectar collection took place in April (Figure 4). In December, there was little pollen collection and no resin collection by the two colonies, but great amounts of nectar were collected (Figure 5). Colony 2 collected both a larger amount of resin and more often, when compared to Colony 1 . Bees without loads were observed all over the year.

\section{Discussion}

As results show, Colony 1 (strong) collected nectar earlier and pollen and nectar in greater amounts than Colony 2 (intermediate), as was observed for Melipona bicolor bicolor, among which the collection of resources begins earlier in strong colonies than in intermediate and weak colonies (Hilário et al., 2000). Usually, weaker colonies produce smaller bees than their stronger counterparts (Lacerda et al., 1991) and larger bees forage earlier (Käpylä, 1974), a fact confirmed by Hilário et al. (1998), through chronobiological analysis of Melipona bicolor bicolor. However, the pollen collection pattern in both colonies changed according to the length of the day and climatic period considered. In the periods of rainfalls, highest temperatures and longest days, Colony 2 collected pollen earlier than Colony 1 .

Low temperatures proved to be a limiting factor against external activity in the study area. In May, the temperature of $14.1{ }^{\circ} \mathrm{C}$ at the beginning of the morning was lower than normal, which meant that the bees only came out to forage at about 9 hours, when the temperature reached $19.6{ }^{\circ} \mathrm{C}$. Corbet et al. (1993) reported that there is a limited range of microclimatic conditions whereby flight can take place and, therefore, restrictions on the foraging of bees.

The ideal temperature and relative humidity ranges for flight activity vary considerably between bees of different species. The optimal values of relative humidity and temperature for flight activity and foraging for most Melipona species are between 70 and $90 \%$ and approximately $20{ }^{\circ} \mathrm{C}$ (Kleinert-Giovannini and ImperatrizFonseca 1986; Bruijn et al., 1991; Hilário et al., 2000). However, Guibu et al. (1984) observed that flight activity of Melipona quadrifasciata quadrifasciata began at $13{ }^{\circ} \mathrm{C}$ and reached a maximum between 14 and $16{ }^{\circ} \mathrm{C}$ and 80 and $89 \%$ of relative humidity. External activity of Melipona bicolor bicolor occurred mainly in the morning, when relative humidity was high $(80-89 \%)$ and the

Table 2. Comparison of the acrophases for nectar and pollen collection by foragers of Melipona rufiventris between the various climatic periods in the region of Ubatuba. Significance of the acrophases given by Rayleigh's test.

\begin{tabular}{|c|c|c|c|c|c|c|c|c|c|c|c|c|}
\hline \multirow[t]{2}{*}{ Colony } & \multicolumn{3}{|c|}{ May-August } & \multicolumn{3}{|c|}{ September-December } & \multicolumn{3}{|c|}{ January-March } & \multicolumn{3}{|c|}{ April } \\
\hline & 1* & $2 * *$ & Total & $1 *$ & $2 * *$ & Total & $1^{*}$ & $2 * *$ & Total & 1* & $2 * *$ & Total \\
\hline $\mathrm{N}^{\circ}$ of nectar loads & 256 & 170 & 426 & 507 & 328 & 835 & 467 & 161 & 628 & 285 & 96 & 381 \\
\hline Acrophase (h:min) ${ }^{1}$ & $10: 31$ & 10:46 & $10: 37$ & $9: 31$ & $9: 43$ & $9: 36$ & $8: 56$ & $9: 56$ & $9: 12$ & $8: 47$ & $8: 59$ & $8: 50$ \\
\hline $\mathrm{r}$ & 0.847 & 0.825 & 0.838 & 0.744 & 0.787 & 0.761 & 0.613 & 0.627 & 0.612 & 0.772 & 0.768 & 0.771 \\
\hline Conclusion ${ }^{2}$ & S & S & S & S & S & S & S & S & S & S & S & S \\
\hline $\mathrm{N}^{\circ}$ of pollen loads & 52 & 46 & 98 & 39 & 46 & 85 & 214 & 77 & 291 & 22 & 12 & 34 \\
\hline Acrophase (h:min) ${ }^{1}$ & $10: 33$ & $10: 33$ & $10: 33$ & $7: 29$ & $8: 07$ & $7: 49$ & $7: 01$ & $6: 07$ & $6: 46$ & $7: 32$ & $6: 39$ & $7: 13$ \\
\hline $\mathrm{r}$ & 0.825 & 0.798 & 0.812 & 0.919 & 0.841 & 0.873 & 0.831 & 0.866 & 0.836 & 0.939 & 0.987 & 0.950 \\
\hline Conclusion $^{2}$ & S & S & S & S & S & S & S & S & S & S & S & S \\
\hline
\end{tabular}

${ }^{1}$ Local time: reference $=$ midnight local $=00^{\circ} ;{ }^{2} \mathrm{~S}=$ significant $(\mathrm{p}<0.05)$; $*$ strong; and $* *$ intermediate.

Table 3. Comparison of the acrophases for nectar and pollen collection by foragers of Melipona rufiventris between the various climatic periods of the year, using Watson-William's test.

\begin{tabular}{|c|c|c|c|c|c|c|c|c|}
\hline & \multicolumn{4}{|c|}{ Pollen } & \multicolumn{4}{|c|}{ Nectar } \\
\hline & \multicolumn{2}{|c|}{ Colony 1} & \multicolumn{2}{|c|}{ Colony 2} & \multicolumn{2}{|c|}{ Colony 1} & \multicolumn{2}{|c|}{ Colony 2} \\
\hline & $\mathbf{F}$ & $\mathbf{F}_{\text {critical }}$ & $\mathbf{F}$ & $\mathbf{F}_{\text {critical }}$ & $\mathbf{F}$ & $\mathbf{F}_{\text {critical }}$ & $\mathbf{F}$ & $\mathbf{F}_{\text {critical }}$ \\
\hline May-Aug x Sept-Dec & $49.26^{*}$ & 3.96 & $22.92 *$ & 3.95 & $24.50 *$ & 3.86 & $19.25 *$ & 3.87 \\
\hline May-Aug x Jan-Mar & $92.44 *$ & 3.86 & $104.81 *$ & 3.92 & $41.44 *$ & 3.86 & $5.78 *$ & 3.87 \\
\hline May-Aug x April & $32.39 *$ & 3.98 & $29.31 *$ & 4.03 & $64.86^{*}$ & 3.86 & $29.72 *$ & 3.87 \\
\hline Sept-Dec x Jan-Mar & 1.60 & 3.89 & $25.08 *$ & 3.92 & $7.05^{*}$ & 3.86 & 0.58 & 3.87 \\
\hline Sept-Dec $x$ April & 0.01 & 4.03 & $5.36^{*}$ & 4.36 & $11.69^{*}$ & 3.86 & $5.42 *$ & 3.87 \\
\hline Jan-Mar x April & 1.18 & 3.89 & 0.90 & 3.96 & 0.32 & 3.86 & $5.01 *$ & 3.89 \\
\hline
\end{tabular}

$*$ = significant difference $(\mathrm{p}<0.05)$. 

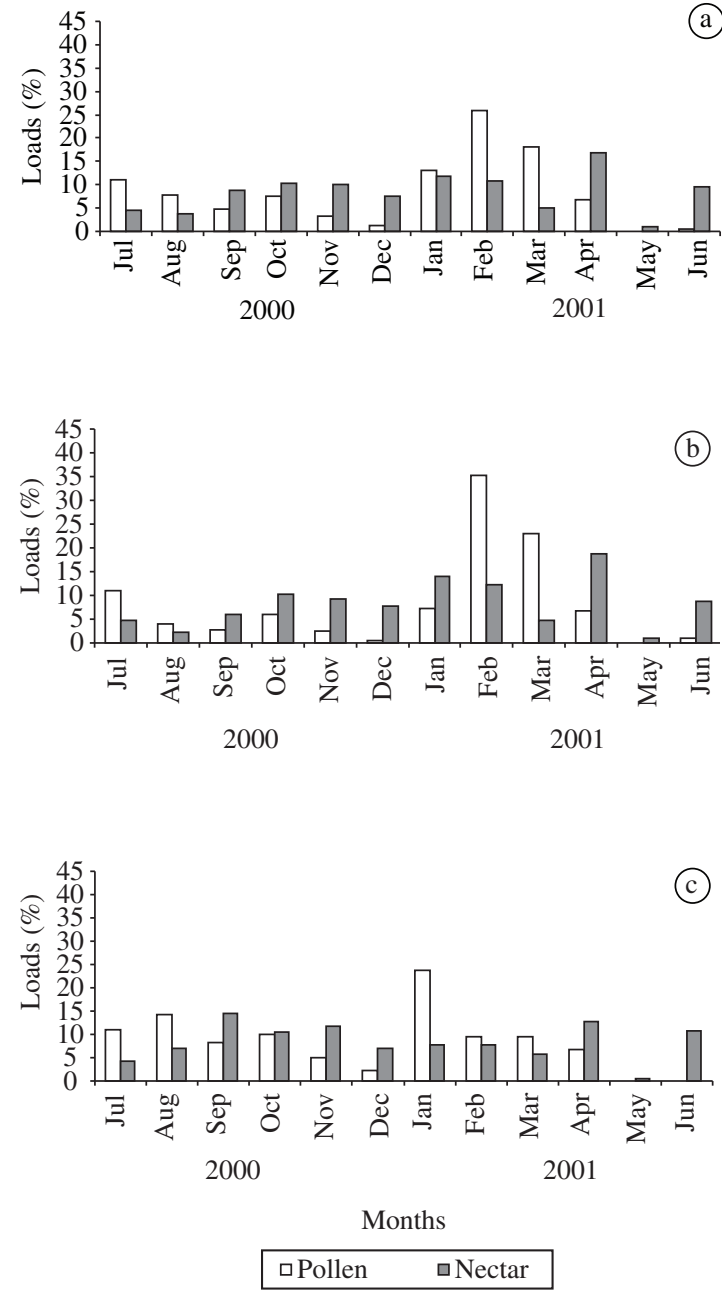

Figure 4. Seasonal variation in the collection of nectar and pollen by Melipona rufiventris in Ubatuba, SP. a) Colony 1 and 2; b) Colony 1; and c) Colony 2.

temperature moderate $\left(18^{\circ} \mathrm{C}\right)$, and the minimum temperature for external activity was $11^{\circ} \mathrm{C}$ (Hilário et al., 2000). Foragers of Melipona rufiventris colonies, located in a savanna area in Minas Gerais, began their flight activity at $13.5^{\circ} \mathrm{C}$, but peak activity occurred at $22{ }^{\circ} \mathrm{C}$ and there was relative humidity of $60.3 \%$ (Pompeu et al., 2002). However, in the Atlantic forest of Ubatuba, M. rufiventris begins external activity when temperature reaches values between 16 and $19{ }^{\circ} \mathrm{C}$, with activity peaks around $24{ }^{\circ} \mathrm{C}$ and between 70 and $90 \%$ relative humidity. Hence, the ideal values for temperature and relative humidity vary according to the species under study, as well as their size (Hilário et al., 2000), and also with the environmental conditions to which the individuals are subjected.

The positive correlation between relative humidity and flight activity described in this work was also observed for several species of Melipona (Guibu et al., 1984; Biesmeijer, 1997; Hilário et al., 2000), as well as an unexpected positive relationship between this activity and

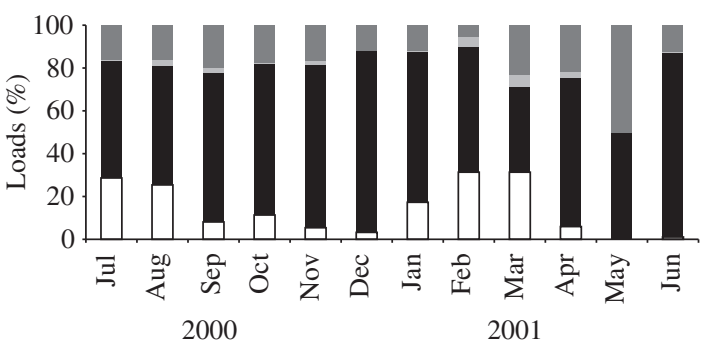

(b)

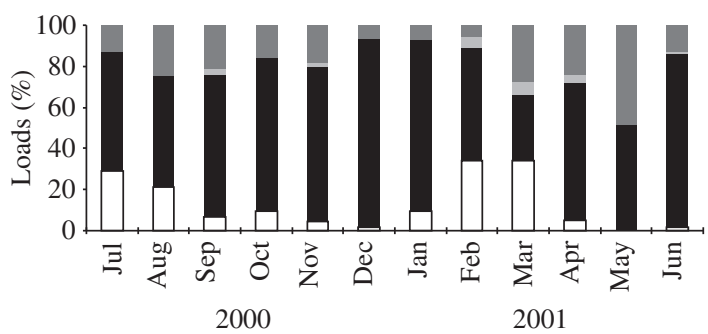

(c)

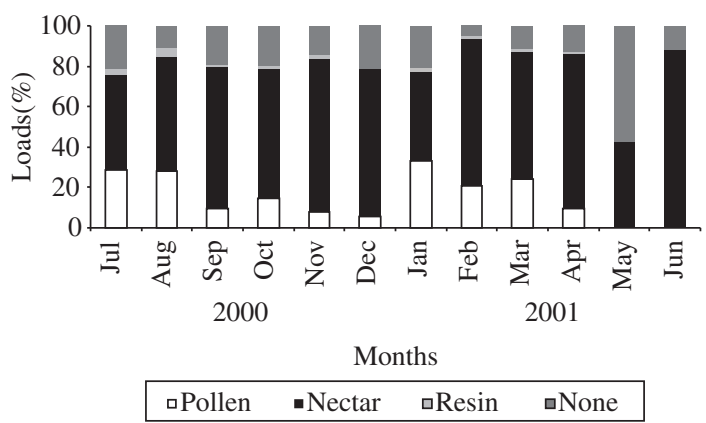

Figure 5. Seasonal frequency (\%) of foragers of Melipona rufiventris entering the colony with or without materials a) Colony 1 and 2; b) Colony 1; and c) Colony 2 .

the temperature and light intensity (Biesmeijer, 1997). However, we know that there is a range of optimum temperature for foraging and that this activity cannot increase indefinitely in accordance with this abiotic factor. Heard and Hendrikz (1993) affirm that temperature and light intensity are the main factors that affect flight activity of Trigona carbonaria in Australia, initially imposing limits outside of which external activity ceases and, later, within these limits correlating with this activity.

Some authors have reported that peaks of pollen collection for the genus Melipona occurred at the beginning of the morning and that of nectar at the end of the morning and in the afternoon, considering it as a standard behavioral pattern for the genus (Sommeijer et al., 1983; Roubik and Buchmann, 1984; Bruijn et al., 1991; Bruijn and Sommeijer, 1997; Biesmeijer, 1997; Pierrot and Schlindwein, 2003). However, for Melipona rufiventris, the two peaks were close, occurring between 6 hours and 9 hours. 
We noticed that if one only considers the months with shorter days, the peaks of pollen and nectar collection occur still closer, with the same peaks at 9 hours (Table 2). In the months with longer days, the peaks stand apart by about two hours, and the pollen peak occurs since the first moments of light within the forest.

The pattern observed in the shorter day period, with pollen peak collection occurring later than expected (ca. 9 hours), has also been described by Bruijn et al. (1991) and Bruijn and Sommeijer (1997) for Melipona favosa, kept inside a greenhouse at the University of Utrecht.

Peaks of pollen and nectar collection occurred together in the coldest and driest period of the year, which presents shorter days (on average 11 hours 46 minutes). After this period, collection peaks gradually move apart along with the increase of temperature, rainfall and length of day.

For Melipona rufiventris, the increase in the number of hours of light, temperature and humidity, from September/October to March in the study area, appears to be important for the beginning of the foraging activity in the first hours of daylight. Furthermore, this period coincides with the blooming of most arboreal species in the area (Morellato et al., 2000).

Most studies of comparative foraging behavior of Melipona species were carried out in areas of low latitudes, close to the Caribbean region (Sommeijer et al., 1983; Roubik and Buchmann, 1984; Biesmeijer, 1997; Bruijn and Sommeijer, 1997). When compared to subtropical areas (as this study site) these areas present little variation in day length, temperature and relative humidity throughout the year and a remarkable flowering synchronization of many tree species during the dry season (Janzen, 1967). Cortopassi-Laurino (2004) also observed for six species of Melipona, in the Amazon region, that bees collected much more pollen in the dry season, and that they shift to resin and mud collection during the rainy season. Consequently, it is possible to explain why the foraging pattern observed in this study is not similar to that described for Melipona genus in these regions.

Resin collection took place in two periods of the day: the first coincided with the moment of greatest activity of nectar and pollen collection for the colonies; and the second with the moment of least activity. According to Bruijn and Sommeijer (1997), bees of the genus Melipona collect resin in periods of little nectar and pollen collection, because foragers would be changing from one resource to another at certain points in time. Melipona rufiventris, however, was observed on various occasions to be carrying both nectar and resin, especially in Colony 2.

The higher number of resin loads in Colony 2 can be explained by their defensive behavior; these bees launch themselves against the invader, and on colliding with their body they deposit resin on it. Colony 1, although aggressive, relied on intimidation by noise and a great number of workers flying around the head of the invader, without actually coming into contact. Furthermore, while Colony 1 was just moved from the hillside to a strip of coastal wooded land, Colony 2 was introduced from another area, and recently introduced colonies tend to collect more material for construction inside the box (Biesmeijer, 1997). The increase of resin collection in Colony 1 from February to March was probably due to the appearance of holes in the bottom of the box which the bees covered with this material.

The great number of pollen loads collected from January to March can be explained through the floral phenology of the area, since this is the time of blooming peak, associated with the highest temperatures and longest days. Talora and Morellato (2000) have described an increase in the number of species in flowers on the belt of coastal wooded land from November, with a peak in December and January, then declining in June until the coldest months. However, December proved to be an unfavorable month for pollen collection by the foragers.

As shown, the daily foraging pattern of Melipona rufiventris varied throughout the year in the study area. This variation was related to seasonal changes of a group of environmental conditions, such as day length, temperature and relative humidity of the air as well as the availability of resources.

Acknowledgments - We wish to thank Lilian Parpineli for her help in the field work and Dr. Sérgio Dias Hilário for comments. This study was part of the thesis presented by the first author to the Graduate Ecology Program, USP, in partial fulfillment of the requirements for obtaining the Ph.D degree. This study was supported by a grant given to the first author by FAPESP (98/13147-8)

\section{References}

BATSCHELET, E., 1981, Circular statistics in biology, Academic Press, London.

BIESMEIJER, JC., 1997, The organization of foraging in stingless bees of genus Melipona: an individual-oriented approach, Ph.D. thesis, Universität Utrecht, Utrecht.

BRUIJN, LLM. and SOMMEIJER, MJ., 1997. Colony foraging in different species of stingless bees (Apidae, Meliponinae) and the regulation of individual nectar foraging. Insectes Soc., vol. 44, no. 1, p. 35-47.

BRUIJN, LLM., HERK, MJ. VAN and SOMMEIJER, MJ., 1991. Some observations on flight activity and foraging of workers of the stingless bees Melipona favosa (Apidae, Meliponinae) in a large green house. Acta Horticulturae, vol. 282, p. 116-120.

CAMILLO-ATIQUE, C., 1974. Variabilidade docomportamento de Melipona rufiventris rufiventris (Hymenoptera, Apoidea). MSc. Dissertation. Departamento de Genética, Faculdade de Medicina, USP, Ribeirão Preto, 147p.

CORBET, SA., FUSSEL, M., AKE, R., FRASER, A., GUNSON, C., SAVAGE, A. and SMITH, K., 1993. Temperature and pollination activity of social bees. Ecol. Entomol., vol. 18, no. 1 , p. 17-30.

CORTOPASSI-LAURINO, C., 2004, Seasonal strategies of harvesting by Melipona sp. in the Amazon region. In: Proceedings of the $8^{\text {th }}$ IBRA International Conference on 
Tropical Bees and VI Encontro sobre Abelhas, Ribeirão Preto (SP), Brazil, p. 258-263.

GUIBU, LS. and IMPERATRIZ-FONSECA, VL., 1984. Atividade externa de Melipona quadrifasciata quadrifasciata Lepeletier (Hymenoptera, Apidae, Meliponinae). Cienc. \& Cult. Supl., vol. 36, no. 7, p. 623.

HEARD, TA. and HENDRIKZ JK., 1993, Factors influencing flight activity of colonies of stingless bee Trigona carbonaria (Hymenoptera: Apidae). Aust. J. Zool., vol. 41, no. 4, p. 343-353.

HERRERA, OM., LEOPOLDO, PR., KROLL, M. and ZUCCARI, ML., 1997. Agrupamento de estações climatológicas localizadas no Estado de São Paulo, utilizando-se análise multivariada. Eng. Agr. Jaboticabal, vol. 16, no. 3, p. 34-42.

HILÁRIO, SD., GIMENES, M. and IMPERATRIZ-FONSECA, VL., 1998. The influence of colony's state in circadian rhythms on flight activity of Melipona bicolor bicolor Lepeletier (Hymenoptera, Apidae, Meliponinae). In: Proceedings of the XIII International Congress of IUSSI, Flinders University Press, Adelaide, Austrália, p. 206.

HILÁRIO, SD., IMPERATRIZ-FONSECA, VL. and KLEINERT, AMP., 2000. Flight activity and colony strength in the stingless bee Melipona bicolor bicolor (Apidae, Meliponinae). Revta. Bras. Biol., vol. 60, no. 2, p. 299-306.

IWAMA, S., 1977. A influência dos fatores climáticos na atividade externa de Tetragonisca angustula (Apidae, Meliponinae). Bolm. Zool. Univ. S. Paulo, vol. 2, p. 189-201.

JANZEN, DH., 1967. Synchronization of sexual reproduction of trees within the dry season in Central America. Evolution, vol. 21 , no. 3, p. 620-637.

KÄPYLÄ, M., 1974. Diurnal flight activity in a mixed population of Aculeata (Hym.). Ann. Entomol. Fenn., vol. 40, no. 2, p. 61-69.

KLEINERT-GIOVANNINI, A., 1982. The influence of climatic factors on flight activity of Plebeia emerina Friese (Hymenoptera, Apidae, Meliponinae) in winter. Revta. Bras. Ent., vol. 26, no. 1, p. 1-13.

KLEINERT-GIOVANNINI, A. and IMPERATRIZ-FONSECA, VL., 1986. Flight activity and climatic conditions: responses by two subspecies of Melipona marginata Lepeletier (Apidae, Meliponinae). J. apic. Res., vol. 25, p. 3-8.

KÖPPEN, W., 1948, Climatologia, Fondo de Cultura Econômica, México.
LACERDA, LM., ZUCCHI, R. and ZUCOLO, FS., 1991. Colony condition and bionomic alterations in Geotrigona inusitata (Apidae, Meliponinae). Acta Biol. Par, vol. 20, no. 1-4, p. 109-123.

MORELLATO, LPC., TALORA, DC., TAKAHASI, A., BENCKE, CC., ROMERA, EC. and ZIPPARRO, VB., 2000. Phenology of Atlantic Rain Forest: a comparative study. Biotropica, vol. 32, no. 4B, p. 811-823.

PIERROT, LM. and SCHLINDWEIN, C., 2003. Variation in daily flight activity and foraging patterns in colonies of uruçu Melipona scutellaris Latreille (Apidae, Meliponini). Rev. Bras. Zool., vol. 20, no. 4, p. 565-571.

POMPEU, MS., SOARES, SM. and SILVEIRA, FA., 2002, Atividade de forrageamento de Melipona rufiventris (Meliponina - Apinae). In: Anais XXIV Congresso Brasileiro de Zoologia, Itajaí, SC, p. 195.

RAMALHO, M., IMPERATRIZ-FONSECA, VL., KLEINERTGIOVANNINI, A. and CORTOPASSI-LAURINO, M., 1985. Exploitation of floral resources by Plebeia remota (Holmberg) (Apidae, Meliponinae): floral preferences. Apidologie, vol. 16, no. 3, p. 307-329.

RAMALHO, M., KLEINERT-GIOVANNINI, A. and IMPERATRIZ-FONSECA, VL., 1989. Utilization of floral resources by species of Melipona (Apidae, Meliponinae): floral preferences. Apidologie, vol. 20, no. 3, p. 185-195.

ROUBIK, DW., 1989, Ecology and natural history of tropical bees, Cambridge Univ. Press, Cambridge, UK.

ROUBIK, DW. and BUCHMANN, SL., 1984. Nectar selection by Melipona and Apis mellifera (Hymenoptera: Apidae) and the ecology of nectar intake by bee colonies in a tropical forest. Oecologia, vol. 61, no. 1, p. 1-10.

SOMMEIJER, MJ., DE ROOY, GA., PUNT, W. and BRUIJN, LLM., 1983. A comparative study of foraging behaviour and pollen resource of various stingless bees (Hym., Meliponinae) and honey bees (Hym., Apinae) in Trinidad, West-Indies. Apidologie, vol. 14, no. 3, p. 205-224.

TALORA, DC. and MORELlATO, PC., 2000. Fenologia de espécies arbóreas em floresta de planície litorânea do sudeste do Brasil. Revta. brasil. Bot., vol. 23, no.1, p. 13-26.

ZAR, JH., 1999, Biostatistical analysis, Prentice Hall, Upper Saddle River - New Jersey. 